\title{
Utilization of Aloe vera as Natural Preservative for Banana Var. Golden Kirana
}

\author{
Indinah Dwi Wahyu Palupi ${ }^{1)}$, Nurul Aliyah' ${ }^{1)}$, Adinda Gita ${ }^{1)}$, Sisca Nur Rohima ${ }^{1)}$ \\ ${ }^{1}$ SMA Negeri 1 Lumajang \\ email: pindinah@gmail.com
}

\begin{abstract}
Buah Pisang Mas kirana kini telah memasuki pasar internasional melalui ekspor ke berbagai negara yang ditunjukkan dengan keikutsertaan buah Pisang Mas Kirana dalam pameran internasional APEC di Bali. Kendala yang dihadapi dalam melakukan pemasaran buah pisang Mas Kirana adalah waktu simpan Pisang Mas yang singkat yaitu dari saat mulai masak sampai dengan busuk sekitar 1 minggu. Lidah buaya (Aloe vera) merupakan salah satu jenis tanaman yang dapat dimanfaatkan sebagai pengawet alami karena di dalamnya terdapat kandungan anti bakteri dan antiseptik yang dapat meningkatkan daya tahan serta Asam Amino yang dapat memberikan perbaikan dan pembentukan regenerasi sel.
\end{abstract}

Keywords: Lidah Buaya (Aloe vera), Pisang Mas Kirana, bahan pengawet alami

\section{INTRODUCTION}

Indonesia as an agrarian country, relies on the sector of agro-industry to support the economy. In a report from the Central Statistics Agency (BPS), it appears that more than forty million of the total 115 million Indonesians work in the agro-industry sector. This data shows that this sector is still the favorite for about thirty-four percent of the population in Indonesia.

As one of Indonesia's regions, the Lumajang Regency also relies on the agricultural sector as its economic driving force. The most popular agricultural commodity of Lumajang is Musa paradisiaca var. Golden Kirana. This fruit has also been named the best banana of Lumajang Regency by the Minister of Agriculture through Decree No. 516 of 2005 (pertanian.pemprov.gov.id).

In the national newspaper, Surya, it is reported that Banana var. Golden Kirana had participated in the International exhibition in Bali which was represented by farmer groups Raja Mas Kandang Tepus, Senduro District, Lumajang Regency. Even the farmer group was also invited to attend the Horticulture Expo in Berlin Germany at the end of 2013 (Surya, 2013).

Banana var. Golden Kirana can enter the international market because it has a distinctive aroma and sweet taste. Another character of this banana is having yellow flesh of ripe fruit (pertanian.jatimprov.go.id). Apart from the taste, the preference for this fruit comes from its appearance. It has a medium size, bright yellow skin that is clean and the texture of the fruit is softer than the other type of bananas (Prahardini, et.al:2013).

Behind all the advantages, Banana var. Golden Kirana has weaknesses in terms of a relatively short shelf life. To solve this problem, farmers used to harvest and sell it before rippen. Packaging without the addition of preservatives makes the banana var. Golden Kirana not having additional storage time.

One way that can be taken to overcome this short save time is by adding preservatives. The preservatives used should be natural preservatives because artificial preservatives can have a negative effect on health. Norman in Fathin, et al (2012) explains that artificial preservatives are chemicals that are added to food and inhibit food damage due to decaying microbes such as fungi and bacteria. Some artificial preservatives that have a negative impact are borax and formalin. In Wariyah and Dewi (2013) it is written that borax is a derivative form Boron which is a dangerous and toxic heavy metal. If consumed, it will cause nausea, vomiting, diarrhea, kidney damage and death. As a derivative of heavy metals, borax also inherits its properties which are difficult to decompose and accumulate in the body of living things.

Benson in Wariyah and Dewi (2013) also explained other types of preservatives that 
have a negative impact on health, namely formaldehyde. Formaldehyde is more familiar to people's as formalin. This compound is carcinogenic, so it is strictly prohibited to use as a food preservative. The negative impact of using preservatives for food can be suppressed if natural ingredients are used for food preservation.

Aloe vera is a type of plant that can be used as natural preservative because it contains antioxidants which increase endurance and Amino Acid which can provide repair and formation of cell regeneration (Rahayu, 2011). Some countries have used Aloe vera to preserve fresh fruit because Aloe vera does not reduce and change the taste of fresh fruit.

Based on this information, preservation of Banana var. Golden Kirana can be done by providing natural preservatives, namely Aloe vera. Aloe vera has natural preservatives that improve and maintain the quality of Banana. According to the researchers, aloe juice can be used as a natural preservative to replace sulfuroxide and other synthetic food preservatives, the results obtained are that food is healthier. Aloe has approximately 250 species spread in the world. The complete classification of Aloe vera is as follow:

\section{Divisio : Spermatophyta \\ Classis : Monocotyledone \\ Ordo : Liliales \\ Familia : Liliciae \\ Genus : Aloe \\ Spesies : Aloe vera}

Based on the Liliaceae family, this plant has the characteristics of herbs or shrubs with rhizome roots, the leaves sit at the base of the stem above the ground (Steeniss, 2008: 142). Morphologically, Aloe vera has ensiformis leaf shape. Leaves are said to have the shape of a sword when the cross section is flat and very long but the edges of the leaves are thinner and in the middle part of the leaf is thick (Tjitrosoepomo, 2011). While based on the flesh of the leaves, this plant is called, has Carnosus leaf with a characteristic of very thick and runny (Rosanti, 2013).

Many researchers believe that Aloe juice works as a natural protector from the rapid decaying process. This juice also protects food safely because the results of previous studies suggest that aloe juice contains components of antibiotics and antifungal which can inhibit microorganisms so as to prevent the onset of disease.

This study aims to determine whether Aloe vera can be used as a natural preservative for Golden Kirana.

\section{RESEARCH METHOD}

Research technique was carried out by interviews and laboratory research. Interviews were conducted to determine the normal saving time of banana var. Golden Kirana without the preservation process. Laboratory research was conducted to test the differences in the conditions of the bananas with different treatments.

Laboratory research was carried out through several stages including the process of making aloe's leaf juice, the application process on banana and the observation process of banana skin morphology when different treatments were carried out. Aloe's leaf juice was done by removing the edges of the leaves and peeling the skin of the leaves and then taking the meat part of the leaves. The leaf meat then mashed using a blender. The juice was evenly divided into 2 portions. The first was directly applied to the banana peel, while the second portion was diluted in water $(1: 1)$ before being applied.

Treatment of bananas was done by applying a smooth aloe leaf juice on the skin of several Bananas which have the same level of maturity. There were three treatment groups used; pure juice, water-based juice, and no treatment. All bananas taken from the same comb to ensure the same level of maturity. Morphological observations were presented in the form of descriptions including skin color, appearance of spots on the skin and texture of banana's peel.

\section{RESULT AND DISCUSSION}

In this study, Aloe vera juice was used as a preservative for Banana var. Golden Kirana. The study was divided into 3 samples, each of which consisted of 2 bananas. Those 3 samples were banana with pure aloe juice, banana with water-based aloe juice and without treatment.

Description of Banana Skin Conditions:

Bioedukasi Vol. XVI. No. 2 Oktober 2018 
Bananas without treatment showed more black patches on the skin than bananas with aloe juice treatments. Among the treatments, pure juice gave significantly better result than water-based juice. Banana treated with pure juice showed slower formation of brown patches hence they had fresher color appearance, also fewer and narrower brown spots. The following figure are the description of morphological conditions for each treatments.
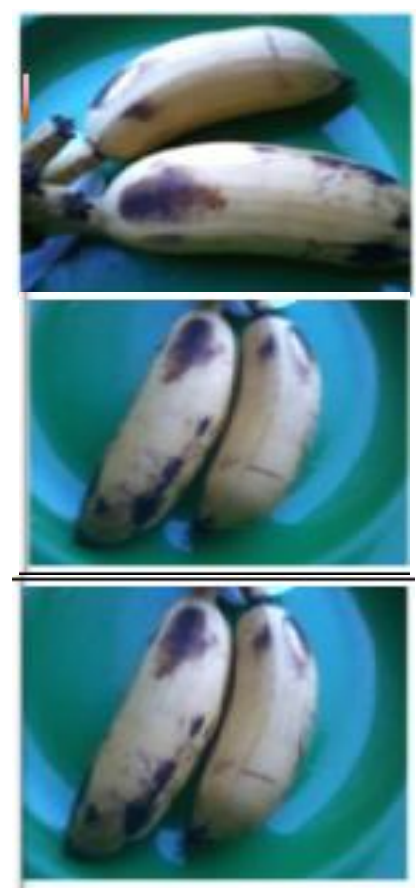

Figure 1. Banana without treatment (from top to bottom; observation on day 1 , day 2 , day $3)$.
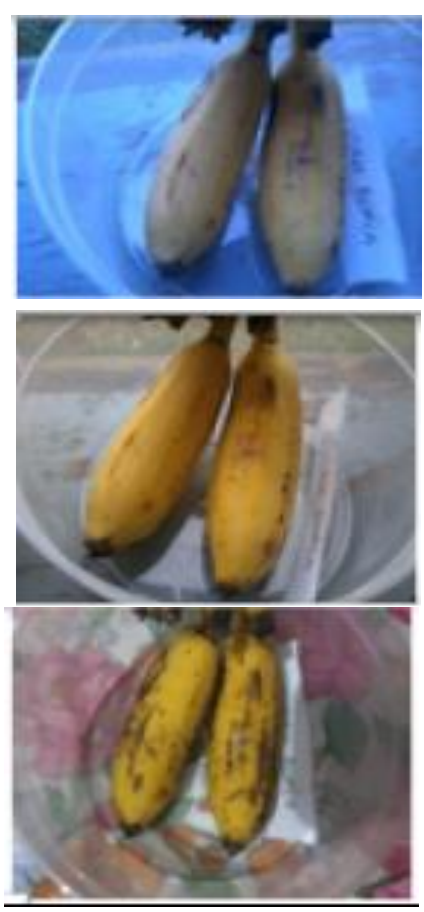

Figure 2. Banana with pure aloe juice (top to bottom; observation on day 1 , day 2 , day 3 ).

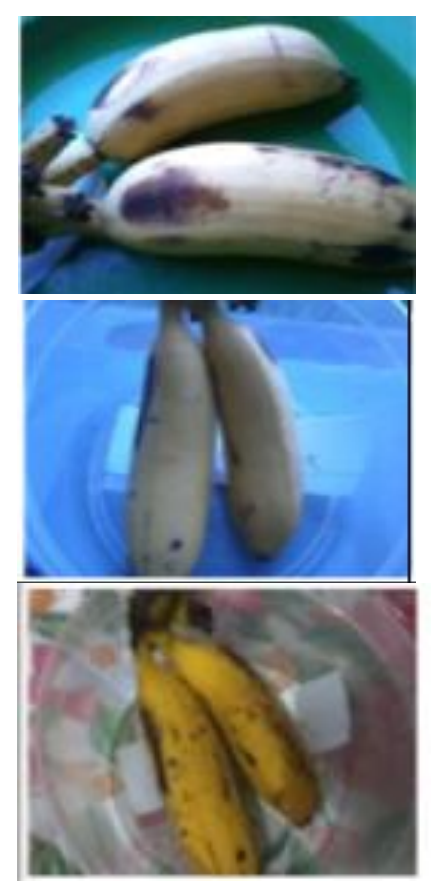

Figure 3. Banana with water-based juice (from top to bottom; observation on day 1 , day 2 , day $3)$. 
Based on observations. it was shown that the banana treated with aloe juice had better conditions than non-treated one. This condition can occur due to the presence of Aponin. A chemical substance in Aloe vera which has the ability to cleanse and to inhibit the growth of harmfull microorganism. Aloe vera also contain Antraquinone and Acemannan, a good anti-bacterial, anti-viral and anti-fungal agents (Rahayu, 2011).

Preservation treatment of banana var. golden kirana with aloe juice could increase the durability of banana var. golden kirana in storage approximately a week from the beginning of maturity level. Therefore, Aloe vera can be used as natural preservative for food.

\section{CONCLUSION}

Aloe vera proven to be good preservative for Banana var. golden kirana. The quality of preservation is as good as chemical preservatives. In addition to its preservative ability, Aloe vera are easily accessible to the community, it does not affect the sweet taste of banana. From this preliminary study, it is hoped that further research will emerge to determine the easier and more practical application of Aloe vera juice.

\section{REFERENSI}

Anonim. 2013. Data Profil Sentra Buahbuahan Pisang Mas Kirana di Kabupaten Lumajang - Jawa Timur 2013. www.pertanian.jatimprov.go.id.

BPS. 2013. Survei Angkatan Kerja Nasional. https://www.bps.go.id

Fathin, dkk. 2012. Chitosan pada Sisik Ikan Bandeng (Chanos chanos) sebagai Alternatif Pengawet Alami pada Bakso. Jurnal Ilmiah Mahasiswa, Vol.2, No. 2, September 2012

Lisdiawati, Rahayu. 2011. Selai Lidah Buaya. Bandung: Amalia Book.
Prahardini, et.al. 2013. Pisang Mas Kirana Primadona dar Jawa Timur. BPTP Jawa Timur.

Prihatin, Trisno. Ciri - ciri pohon Pohon Pisang Mas Kirana.

Rosanti, Dewi. 2013. Morfologi Tumbuhan. Jakarta: Erlangga.

Santoso, Hieronymus Budi. 1995. Sale Pisang. Yogyakarta: Kanisius.

Steenis, dkk. 2008. Flora: untuk sekolah diIndonesia. Jakarta: Pradnya Paramitha.

Surya. 2013. APEC Kenalkan Pisang Mas Kirana ke Pemimpin Dunia. Surya, 5 Oktober 2013.

Tjitrosoepomo, Gembong. 2011. Morfologi Tumbuhan. Yogyakarta: Gadjah Mada University Press.

Wariyah dan Dewi. 2013. Penggunaan Pengawet dan Pemanis Buatan pada Pangan Jajanan Anak Sekolah (PJAS) di Wilayah Kabupaten Kulon Progo-DIY. Jurnal Agritech Vol.33, No.2, Mei 2013.

Bioedukasi Vol. XVI. No. 2 Oktober 2018 